\title{
近赤外分光法を用いた音情報に対する脳賦活反応解析*
}

利根川 洋一 ${ }^{* 1}$ ，綿貫 啓一 ${ }^{* 2}, 3, * 4$

\section{Brain Activity Analysis for Sound Information Using Near-Infrared Spectroscopy}

\author{
Yoichi TONEGAWA and Keiichi WATANUKI ${ }^{* 2}$ \\ *2 Graduate School of Science and Engineering, Saitama University \\ 255 Shimo-okubo, Sakura-ku, Saitama-shi, Saitama 338-8570
}

Human beings feel sound in various ways, depending on the environments. For instance, one hears car's engine sound while driving the car in the way different from while hearing it coming from outdoors inside the house. In this paper, the analysis of brain activation to various sounds was conducted using near-infrared spectroscopy. It turned out that the listening to music and uncomfortable sound decreased oxyHb in the prefrontal cortex. This reaction can be considered the response to the concentration on the sound. It also tuned out that there is a viewpoint that the decrease of oxyHb in a brain does not necessarily mean the the decline in the neural activity but the brain activation reaction. It is expected to qualify audio information extracted from these two regions and to serve the plan of sound design.

Key Words : Near-Infrared Spectroscopy, Brain Activity Analysis, Acoustic Comfort, Psychological Measurement

\section{1. 緒 言}

人が感じる音は，同じ音に対しても環境が異なれば，違った感じ方で捉えられる．例えば，車のエンジン音に 関して，運転をしながら聞く時と，家の中で外からのエンジン音を聞く時では，感じ方が異なると考えられる. 前者は，運転に集中しているのでエンジン音に関して違和感はないが，後者は普段生活しているところにエンジ ン音が聴こえてくるので，不快に感じる可能性がある．また，工場で発する音でも同様に，実際に工場で働いて いる人はあまりうるさいと感じない音でも, 近隣の住民はとてもうるさいと感じている場合もある.このように, 人の音の感じ方は環境が異なることによって同じ音でも様々である.

このように，人間が感じる音は，耳によって収集され，生理的変化を表す電気信号に変換され，感覚神経を通 って脳に送られ処理される. 処理された情報は，運動神経や自律神経によって伝達され，言語や行動になって反 応が起こる. すなわち, 感性として表現される(1). こうした感性を評価する手法は, 心理学的計測と生理学的計 測の 2 種類に分けることができる(2). 心理学的計測法は, 質問紙や調査表を用意して, 言語を通じて感性を定量 化する方法である．最も使用されている手法としては Osgood らが提唱した SD 法(Semantic Differential Technique) がある. 一方で, 生理学的計測法は, 人体の反応を計測することによって感性情報を表す手法である. 計測方法 としては，脳波，血圧，呼気，焦点調節，心電図，心拍数，血流量，筋電図，皮膚温度，皮膚電位，眼球運動な ど様々である. 心理学的計測では, 被験者の認知レベルの調査であるため, 深層的感性を捉えることが難しく, 失敗することが多い(3).

本論文では, 生理学的計測の一つである脳血流に着目し, 近赤外分光法を用いて, 人が感じる音の定量化を実 現することを目的としている．前頭前野と側頭葉を調べることで，音を聞いたときにそれらの部位が，どういっ た関係性にあるのかについて検討を行う，前頭前野は，思考や創造性を担う役割があるとされ，情動を制御した り，記憶コントロールしたりすると考えられている．側頭葉は聴覚処理に関わり，音声や文字の意味に大きく影 響する.この関係性の検討から音情報を定量化することで, サウンドデザインの設計に役立つことが期待される.

\footnotetext{
* 原稿受付 2012 年 4 月 2 日

*1 学生員, 埼玉大学大学院理工学研究科（†338-8570 埼玉県さいたま市桜区下大久保 255)

*2 正員, フェロー, 埼玉大学大学院理工学研究科

*3 埼玉大学アンビエント・モビリティ・インターフェイス研究センター

*4 埼玉大学脳科学融合研究センター

E-mail: watanuki@mech.saitama-u.ac.jp
} 


\section{2. 近赤外分光法}

人間の眼に見える可視光は，生体中では強く散乱するため脳計測を行うときには使用することができない，し かし，近赤外光(700nm 900nm)では，生体中を透過しやすく, 脳皮質を透過して脳の内部まで光が届くようにな る.こうした光の波長帯は「生体の空」とも呼ばれている.こういった現象は，手を白色光に照らしたときに波 長の長い赤い光が透けて見えるので実感ができる.

近赤外分光法は，透過しや寸い近赤外光と血液の中に含まれるへモグロビンの光吸収特性を利用して成り立っ ている. 酸素化へモグロビン $(\mathrm{oxy} \mathrm{Hb})$ と脱酸素化へモグロビン (deoxy Hb) の光吸収スペクトルが異なっており， この違いを利用して, 脳血流の相対的な流量が測定可能となっている. oxy Hb と deoxy Hb のモル分子吸光係数 が既知であれば，遠赤外光を照射することで，濃度変化を測定することが出来る．生体の中で酸素を運んでいる のは，へモグロビンであり，へモグロビン濃度変化を測定することで，脳への酸素の供給，代謝の状態を推定す ることが可能となる.

本研究では, 近赤外光イメージング装置(Near-Infrared Spectroscopy: NIRS) ${ }^{(4)}$ として, 島津製作所製 FOIRE-3000 を用いた．この装置では，780nm， 805nm，830nmの3 波長の近赤外光を照射することで, 精度良く計測を行な っている. NIRS は，他の非侵襲脳機能測定装置に比べ，低拘束で，日常生活に近い環境下で計測が可能である ことや，時間分解能が比較的高いこと $(100 \mathrm{~ms})$, 安価に測定が可能となることが優れている.また，短所として 空間分解能が低いことや, 脳深部や小脳の計測ができないこと, 相対的データのため, 非連続な経時データの比 較が困難であることがあげられる. 先行研究によると, 測定される数值のうち, oxy Hb の変化量が局所脳血流 (regional cerebral blood flow: rCBF)の変化と最も相関があることを示している(5),(6). したがって, 本研究では oxy Hb の変化量に着目して脳活動について述べる.

\section{3. 近赤外分光法による安静時に対する検定手法}

\section{$3 \cdot 1 \quad$ NIRS による安静時における反応}

図 1 は安静時における NIRS で計測されたデータの一例を示す. 図 1 (a), (b)では課題開始前の安静期間におい て明らかな差が生じている. 図 1 (a)では安静時 15 秒後に oxy Hb が上昇しており, 約 $0.03 \mathrm{mmol} / \mathrm{l} \cdot \mathrm{cm}$ ほど上昇し ていることが確認できる。，一方，図 1 (b)では安静開始時から課題開始にかかるまでに, oxy Hb が上昇する傾向を 示していない．このように，同じ安静期間においても脳賦活反応が異なる場合がある.このような現象が考えら れる要因として, 被験者が何かを考えている, 体を動かしている, 眠くなっているなど様々な要因が挙げられる.

図 2 は, 図 1 のデータの課題開始前の安静時におけるヒストグラムを示寸. 図 2 (a)は図 1 (a)の課題開始前の安 静期間をヒストグラムにしたグラフである. 安静期間における oxy Hb の值の最大值と最小值を 50 分割し, 1 分 割中の標本数を示している. 図 2 (b)も同様に図 1 (b)のレスト期間のヒストグラムを示寸.

図 2 (a) と図 2 (b)を比較すると, 図 2 (b)の方が正規分布により近い形となっている. 図 2 (a) は, 山が二つできて おり，正規分布の形とは違う傾向を示している．このように，安静期間中に安静にできているか，できていない かでヒストグラムの傾向が変わってくることがわかる.

\section{$3 \cdot 2$ Jarque-Bera 検定を用いた NIRS の反応に対する検定}

$3 \cdot 1$ 節に述べたように, NIRS における安静時のデータにおいて, 安静になっている時に正規分布になってい ると考えられる. 正規性の検定の一つに Jarque-Bera 検定 ${ }^{(7)}$ がある. Jarque-Bera 検定は尖度 $s$ と歪度 $k$ を用いるこ とで正規分布かどうかを調べる. 観測值 $\left\{x_{1}, x_{2}, \cdots, x_{n}\right\}$ とすると, 尖度 $s$ と歪度 $k$ は次のように定義される.

$$
\begin{aligned}
& s=\frac{1}{n} \sum_{i=1}^{n}\left(\frac{x_{i}-\bar{x}}{\sigma}\right)^{3} \\
& k=\frac{1}{n} \sum_{i=1}^{n}\left(\frac{x_{i}-\bar{x}}{\sigma}\right)^{4}
\end{aligned}
$$


ただし， $\bar{x}$ は観測值の平均値， $\sigma$ は観測值の不偏分散である. 尖度と歪度は，どちらも観測值の分布の形状を 特徵付けるものとしてある指標である. 尖度は尖り具合, 歪度は歪み具合を示している. 尖度の值が 3 より大き ければ，観測值の分布は比較的に尖っており，3 よりも小さければ，尖っていないと判断される．歪度では正の 值のとき，観測值の分布は右に歪んでおり，負の值のときは左に歪んでいると判断される.

Jarque-Bera 検定では，この尖度 $s$ と歪度 $k$ を用いることで，次のような検定統計量 $J B$ を表すことができる.

$$
J B=\frac{n}{6}\left\{s^{2}+\frac{1}{4}(k-3)^{2}\right\}
$$

この検定統計量 $J B$ は, 自由度が 2 のカイ二乗分布に従うことが知られている. 自由度 2 のカイ二乗分布の上 側 $5 \%$ 点は $\chi_{2,0.05}^{2} \doteqdot 5.991$ である. したがって, 正規分布かどうかを調べるためには, 検定統計量 $J B$ が $\chi_{2,0.05}^{2}$ よ り小さいか，大きいかで判断できる．正規分布に従っていれば，安静状態であるといえ，正規分布に従っていな ければ, 安静状態ではないといえる.

ここで，一例として有意水準 $5 \%$ で以下の検定を行う. 帰無仮説を $H_{0}$, 対立仮説を $H_{1}$ とすると次のように表 すことができる.

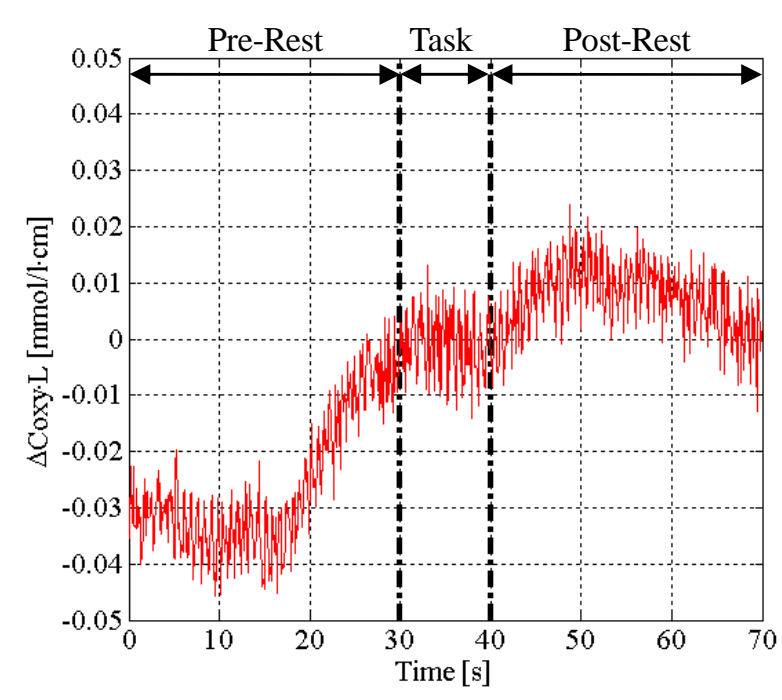

(a) Hemodynamic instability in pre-rest

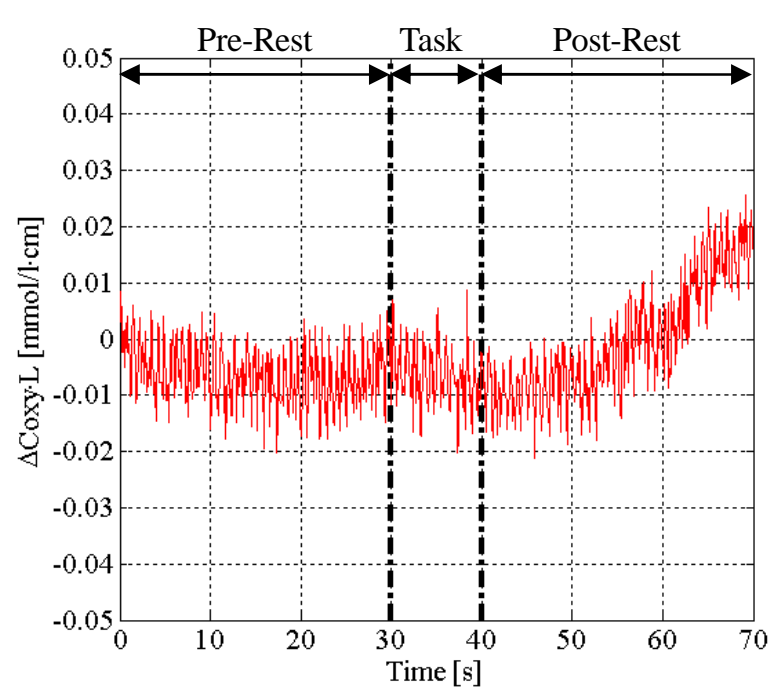

(b) Hemodynamic stability in pre-rest

Fig.1 An example of the NIRS data

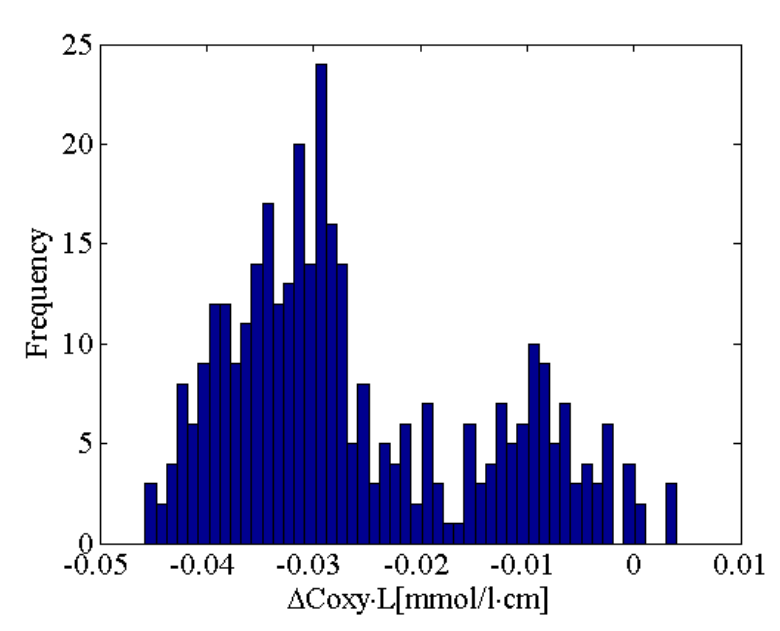

(a) Histogram with hemodynamic instability in pre-rest

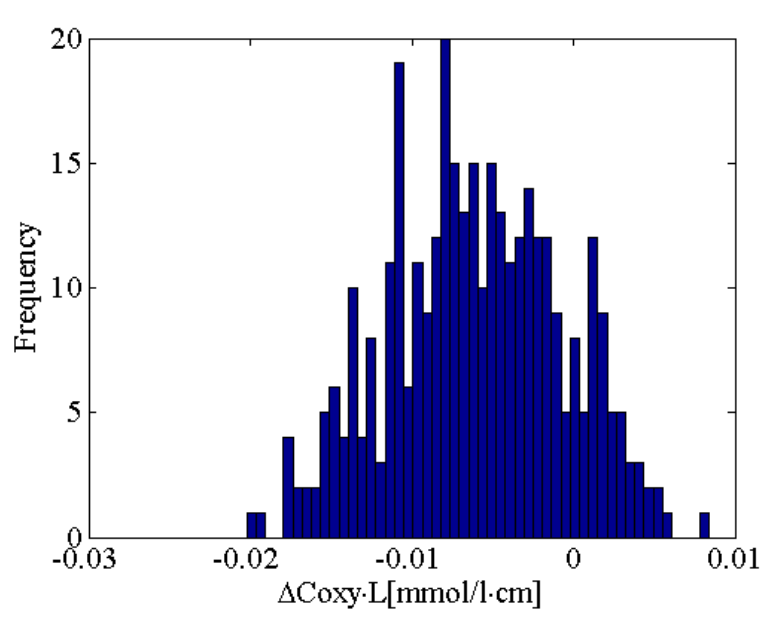

(b) Histogram with hemodynamic stability in pre-rest

Fig.2 Histogram in pre-rest 
$H_{0}:$ 安静時は正規分布に従う

$H_{1}:$ 安静時は正規分布に従わない

図 1 (a) と図 2 (b)の NIRS のデータの安静時における検定を行う. 図 1 (a)での検定統計量は 31.882, 図 1 (b)での 検定統計量は 3.235 となる. 図 1 (a)の検定統計量は $\chi_{2,0.05}^{2} \fallingdotseq 5.991$ よりも大きいので, 有意水準 $5 \%$ で帚無仮説 $H_{0}$ を棄却できる，よって，対立仮説 $H_{1}$ を採択し，正規分布に従わないということになる，一方，図 1 (b)の検定統 計量は $\chi_{2,0.05}^{2} \fallingdotseq 5.991$ よりも小さいので, 有意水準 5\%で帚無仮説 $H_{0}$ を棄却できない. したがって, 正規分布に 従わないとはいえないことになる.

このように, Jarque-Bera 検定を用いることでNIRS のデータの安静時において正規分布になるかどうかを調べ ることが出来る. したがって, 正規分布であれば, 安静期間中に安静になっているといえ, 正規分布でなければ, 安静になっていないといえる. 本研究では, この手法を用いて, データの取捨選択を行う.

\section{4. 音楽に対する脳賦活反応}

\section{$4 \cdot 1$ 実験方法}

被験者は, 20 代前半の健全な男性 1 名である. 被験者は椅子に座り, 安静な状態で音情報を提示される. 外的 なノイズを抑えるために，被験者は閉眼し，イヤホンを使用して音情報を提示する. 本実験では, 音楽と正弦波 の 2 種類の音を使用する. 音楽は, 被験者が聞き慣れた音楽を選択する. 音圧は被験者が適度と判断した音圧を 用いた．正弦波は $0.25 \mathrm{kHz} ， 0.5 \mathrm{kHz} ， 1 \mathrm{kHz} ， 2 \mathrm{kHz} ， 3 \mathrm{kHz} ， 4 \mathrm{kHz} ， 8 \mathrm{kHz}$ の 7 つの異なる周波数を提示する.いず れも音の提示時間は 30 秒とし，音楽はサビの部分を使用する．音楽は，10 回聴取して，脳反応に再現性がある のかを検討する. タスクデザインは，レスト 20 秒，タスク 30 秒，レスト 40 秒とした．測定部位は，国際 10-20 法に基づいて設定し, 思考, 学習, 推論, 注意, 意欲, 情操に関わる部位である前頭前野, および聴覚野, ウェ ルニッケ野，ブローカ野など音の刺激による反応が起こる部位である側頭葉とする.

\section{Frontal cortex}

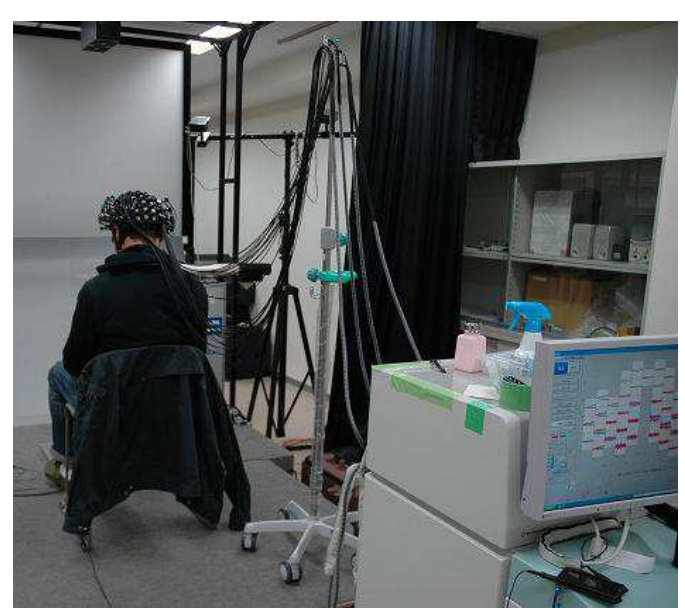

Fig.3 Experimental setup

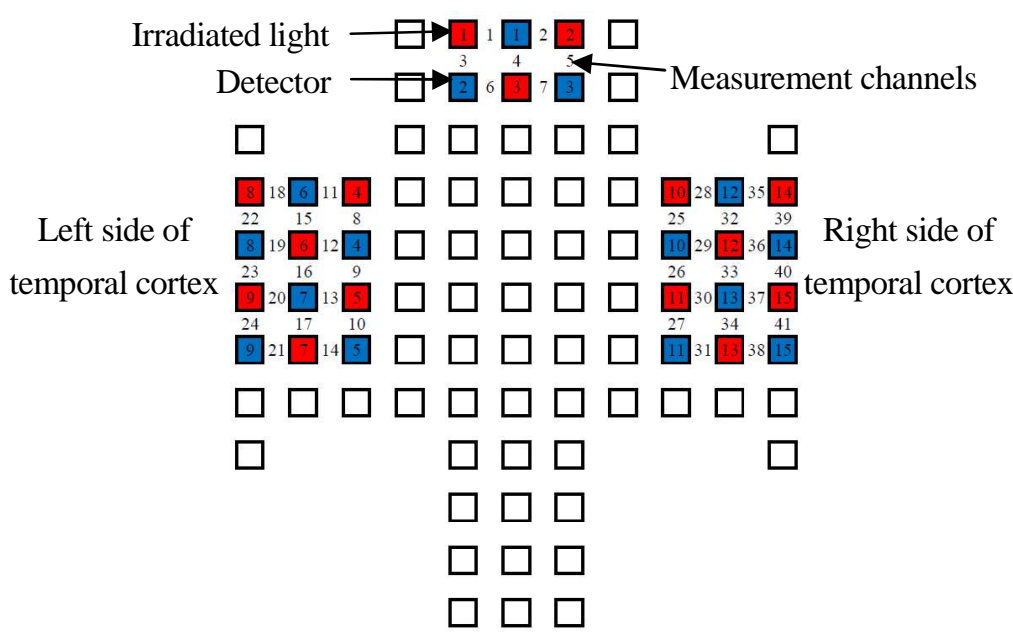

Fig.4 Measurement channel

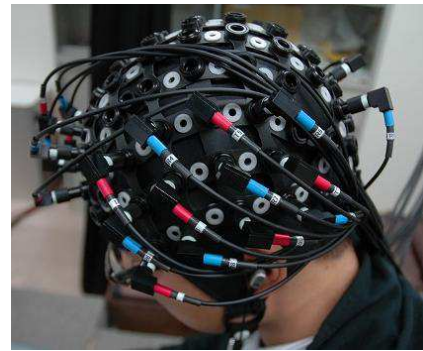

(a) Left side of temporal cortex

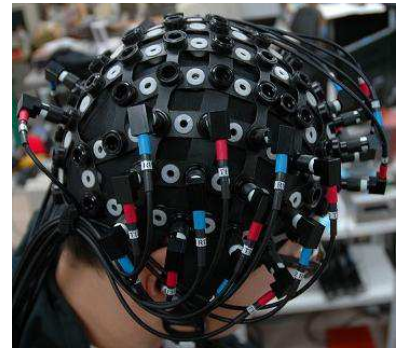

(b) Right side of temporal cortex Fig.5 Measurement sites

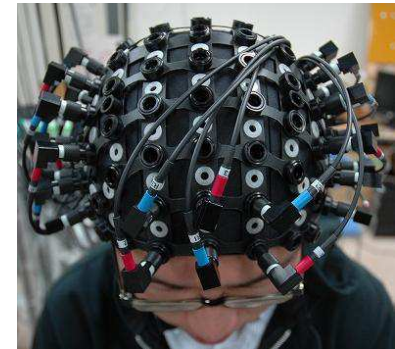

(c) Frontal cortex 


\section{$4 \cdot 2$ 実験結果と考察}

音楽聴取時の前頭葉(Ch.6)での反応を図 6 に示寸. タスク開始時を 0 として補正を行った. 音を聞いてから約 7 秒後に一時的に賦活し，その後，oxy Hb が減少しているのがわかる．また正弦波を聴取したときの脳賦活反応を 図 7 に示す．音を聞いている時に音楽を聴取する時とは違った傾向を示した，音楽を聴取したときでは，oxy $\mathrm{Hb}$ が下がる傾向にあるが，正弦波を聴取したときには，下がる傾向を示さず上がる傾向にあった．このように音を 聞いた時に音の種類によって脳賦活反応に傾向が変わっていることがわかる.

図 7 は，音楽を 10 回聴取したときの聴取開始 10 秒以内での最大 oxy $\mathrm{Hb}$ の平均値と, 聴取終了時の oxy $\mathrm{Hb}$ の 平均值をまとめたグラフである.聴取終了時での oxy Hb は有意水準 $5 \%$ において有意差が認められた $(\mathrm{p}=0.0112)$. 正弦波聴取開始時から 10 秒間の最大 oxy Hb の平均值と聴取終了時の oxy $\mathrm{Hb}$ の平均值では, 有意差が認められな かった $(\mathrm{p}=0.5896)$ 。このように音楽と正弦波を聞いた時では，脳賦活反応が異なる．これは，一般的に被験者に とって意味を持つ音では脳が賦活し，意味を持たない音では賦活しないのではないかと考えることができる.

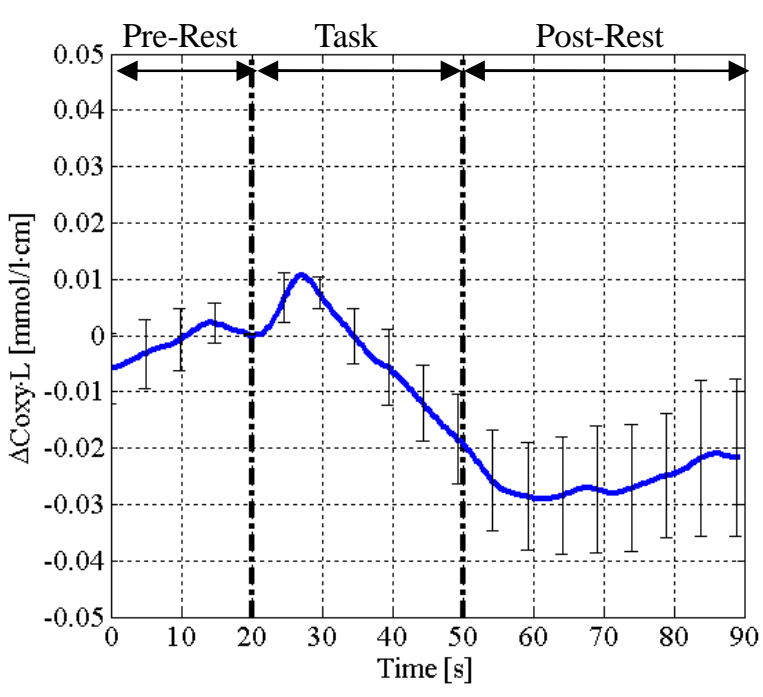

(a) Familiar music

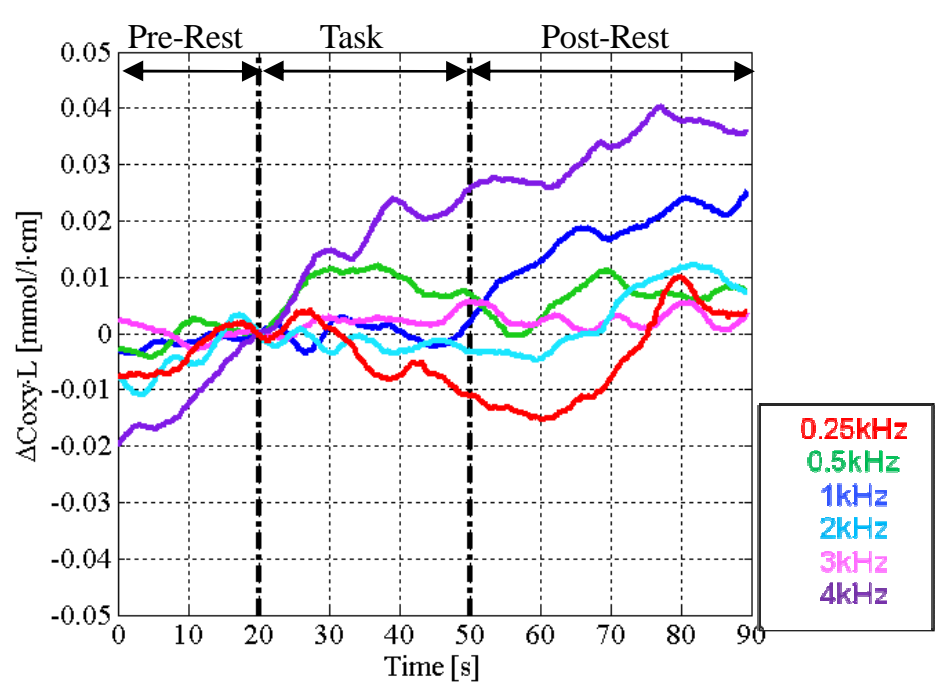

(b) Sine wave

Fig.6 Changes in concentrations of oxy-Hb (Ch.6)

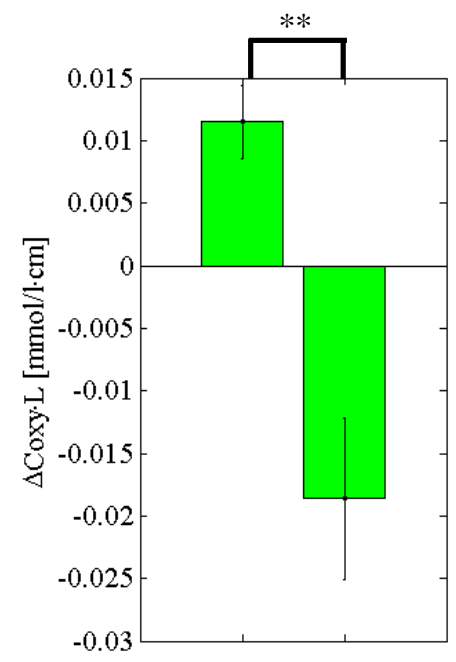

Maximum listening value

The last part of listening value

(a) Familiar music

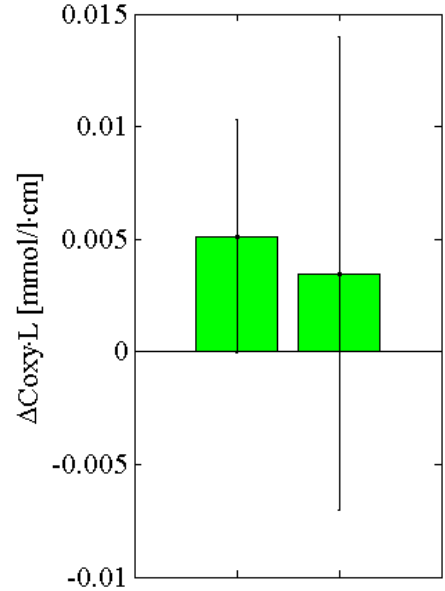

Maximum listening value

The last part of listening value

(b) Sine wave

Fig.7 Comparison between maximum listening value and the last part of listening value $(* *: p<0.01)$ 


\section{5. 不快音に対する脳賦活反応}

\section{$5 \cdot 1$ 実験方法}

本実験では, PCM レコーダ(SONY 製 PCM-D50)を用いて, 引っ掻き音と小鳥のさえずりを採取する. 引っ掻き 音は爪を立てて，それぞれの材料に対して引っ掻いたときの音を録音する．録音されるフォーマットは $96 \mathrm{kHz}$, 24bit の wave ファイルで保存する.

被験者は，図 8 のように椅子に座り，目隠しをして音を聞いてもらう。被験者の横に騷音計を設置し，音の大 きさを測定する．聞いているときは出来るだけ動かないように指示し，音だけに集中してもらう．1つの音を聴 き終わったら，アンケートを実施する．聞いてもらう音は引っ掻き音の 4 種類（ドアの引っ掻き音，金属の引っ 掻き音，テレビ側面の引つ掻き音，黒板の引つ掻き音）と小鳥のさえずりの 5 種類である. 聴取する順番は被験 者毎に変更する. 被験者は 20 代前半の健全な男性 5 名である. 測定部位は, 図 9 に示寸ように前頭前野と右側頭 葉と左側頭葉の 3 つの部位である. タスクデザインはレスト 30 秒, タスク 10 秒, レスト 30 秒で構成する.

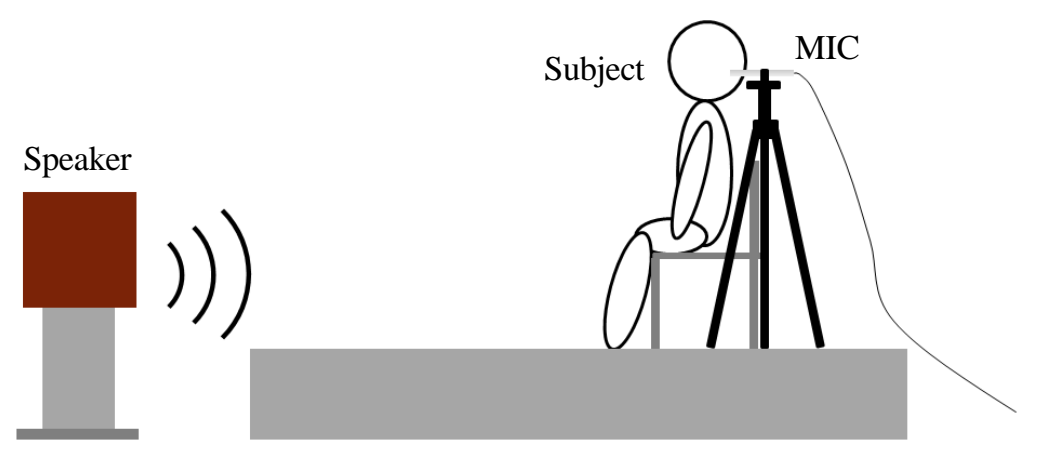

Fig.8 Experimental setup
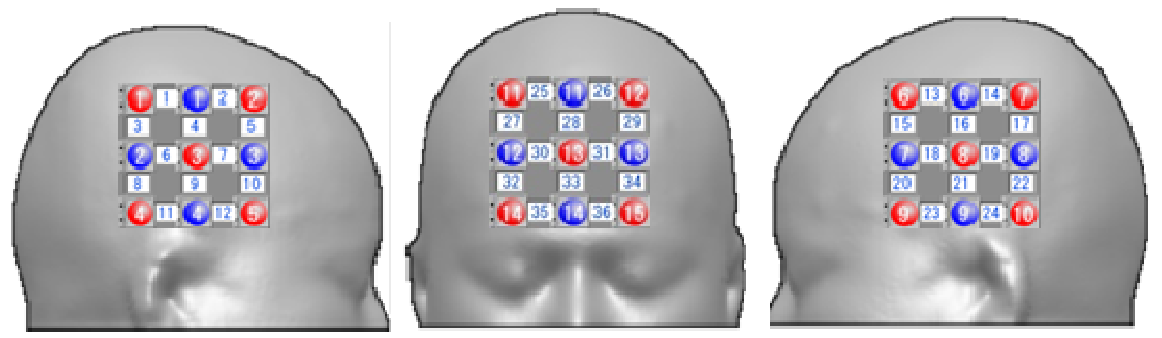

Fig.9 Measurement channels

\section{$5 \cdot 2$ 実験結果と考察}

NIRS で測定されたデータは生体のゆらぎによって，被験者間での比較ができない，そこで，標準化をおこな った後, 被験者間で加算平均を行う。標準化は, 次式で行う.

$$
\operatorname{Oxy}(t)_{\mathrm{Zscore}}=\frac{O x y(t)_{\mathrm{Raw}}-\mu_{\mathrm{Rest}}}{\sigma_{\text {Rest }}}
$$

ただし, $O x y(t)_{\text {Raw }}$ は元の oxy Hb のデータ, $\mu_{\text {Rest }}$ は課題前のレスト中の平均值, $\sigma_{\text {Rest }}$ は課題前のレスト中 の標準偏差である. 図 10 と図 11 は, 標準化し, 加算平均を施した実験結果である. 小鳥のさえずりの聴取時よ りも，金属の板の引つ掻き音の聴取時の方が，oxy Hb が減少することがわかる．このように，不快な音を聴取し た時には, oxy Hb が下がる傾向であることがこの結果から推測できる.

このように, 音楽聴取時と不快音聴取時において, 前頭前野において oxy Hb が下がるという傾向が推測される. シューティング, リズム，ブロック落とし，サイコロパズルゲームをすることによって前頭前野内側部において oxy Hb が減少するという報告 ${ }^{(8)}$ や, 内観（没入感・音楽的な気持ち良さ）と前頭前野正中部における oxy Hb が減 少することと相関があるとされる報告 ${ }^{(9)}$ があることから, 音を聴取することにより集中させられている状態で, 前頭前野において oxy Hb が減少するのではないかと考えられる. 


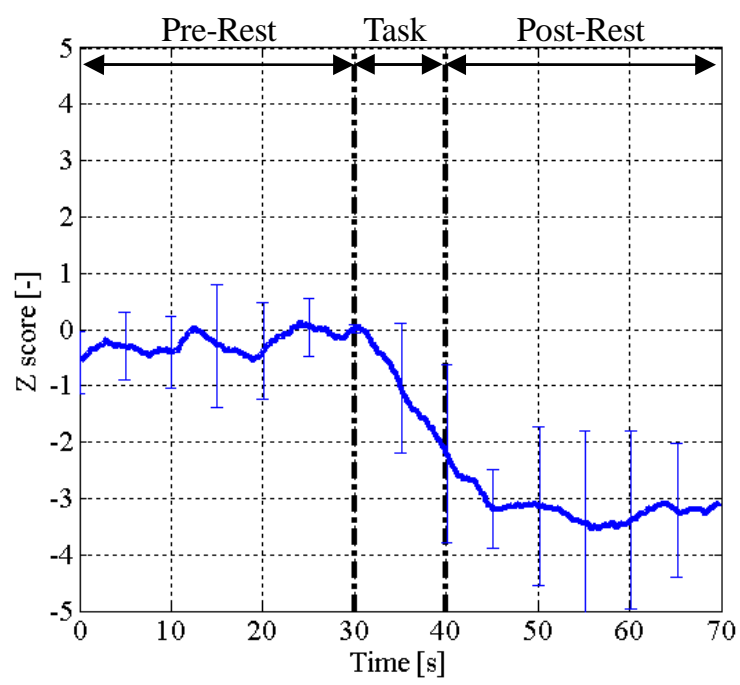

Fig.10 Brain activation for hearing the sound of fingernail scraping a steel sheet $(71.1 \mathrm{~dB})$

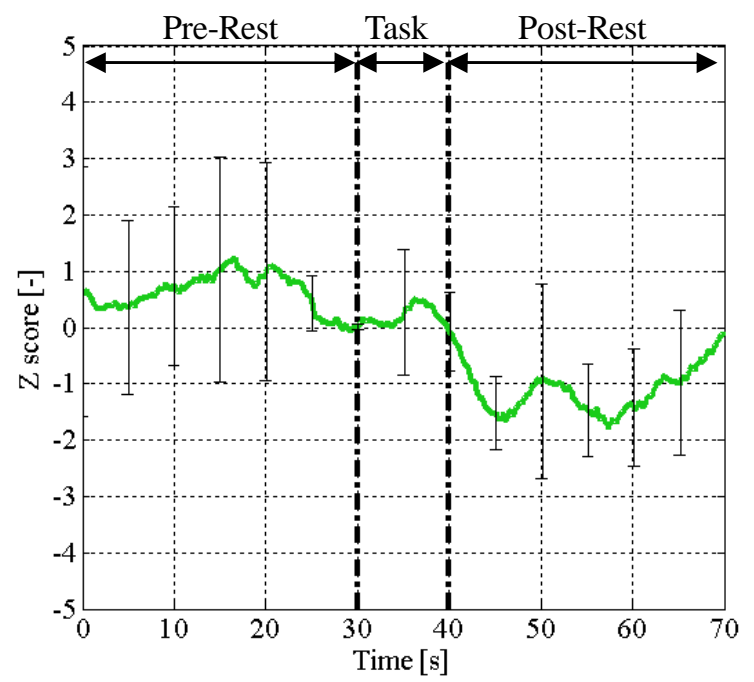

Fig.11 Brain activation for hearing the sound of birdsong $(71.0 \mathrm{~dB})$

\section{6. oxy Hb が減少することに対する考察}

脳において, oxy Hb が減少するということについて言及する. rCBF の増加と神経活動の増加に相関があるこ とを示していることは報告されている ${ }^{(5)}$ が, 必ずしも oxy-Hb の減少が神経活動の低下を意味することとは限らな い. 脳内の毛細血管の直径は, 約 $35 \%$ 伸縮するということが報告されている ${ }^{(10)}$. また, 毛細血管にはグリア細胞 による血流調節機構があることが知られている ${ }^{(11)}$.このことから, 図 12 のように脳が賦活することによって oxy $\mathrm{Hb}$ が不足した時, 小血流や心臓による一時的な血圧上昇によって, 毛細血管内の oxy $\mathrm{Hb}$ を増加させる方法と, 毛細血管の血管床面積を減少させることによる一時的な血流速度の増加による oxy Hb を増加させる方法の二つ が考えられる. 先行研究より, NIRS 測定では血流速度変化の影響を受けないという報告 ${ }^{(1)}$ があるため, 血流速 度変化による NIRS のデータは変動を受けないことを示している. したがって, NIRS で測定された脳賦活反応の 実験結果は，前者であれば， oxy Hb が上昇する結果となり，後者であれば， oxy Hb が減少する結果となる．この ように同じ脳賦活反応においても，NIRSによる結果が異なることが考えられる．前者は主に，運動など体に負 担がかかるような動きをした際に起こる現象, 後者は脳に一時的な負担がかかった時, つまり思考したり, 集中 したりするときなどに起こるような現象であると推察できる. 本研究の場合では, 音を聞くだけの簡単な実験な ため, 後者の音に集中した際に起こる脳賦活反応とみることができる.したがって, 今回 NIRS で測定された oxy $\mathrm{Hb}$ が下がるという反応は，脳賦活反応であるとすることができる.

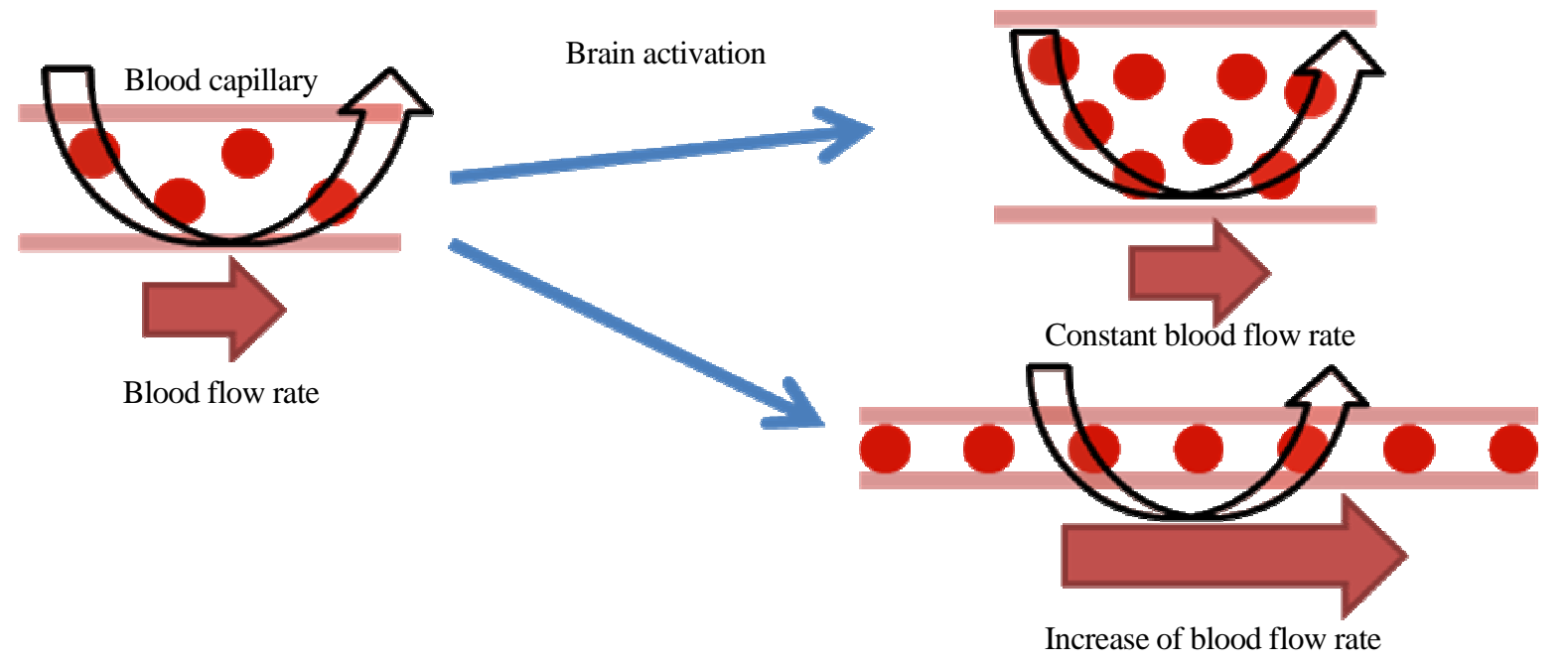

Fig.12 Blood flow mechanism 


\section{7. 結 言}

本論文では，NIRS を用いて様々な音に対する脳賦活反応解析をおこなった．音楽や不快音を聴取することに よって, 前頭前野において oxy Hb が減少することがわかった. この反応は, 音に集中した際に反応したものであ ると考えられる.また, 脳における oxy Hb が減少することは, 必ずしも神経活動が低下寸るという意味ではなく, 脳賦活反応であるという考えを提案した，今後は，NIRS だけではなく，様々な脳機能計測装置を用いることに よって，音を定量化していきたいと考えている.

\section{文献}

（1）辻三郎，感性の科学一感性情報処理へのアプローチー (1997)，サイエンス社.

(2) 亀井且有, 青山美由夏, 木下雄一朗, クーパー・エリック, 星野孝総, “SD 法による心理計測および近赤外分光法 による生理計測にもとづく打楽器音楽の感性評価”, 日本感性工学会研究論文集, Vol.6, No.4 (2006), pp.67-76.

（3）長町三生，“消費者中心の商品開発をめざす感性工学”，日本品質管理学会 (1999), pp.19-27.

（4）島津製作所社製近赤外光イメージング装置 NIRStation（ニルステーション），http://www.med.shimadzu.co.jp/ application/other/t05.html（参照日 2012 年 4 月 2 日）.

(5) Jueptner, M., Weiller, C., "Does measurement of regional cerebral blood flow reflects synaptic activity?- Implications for PET and fMRI", Neuroimage, Vol.2 (1995), pp.148-156.

(6) Hoshi, Y., Kobayashi, N., Tamura, M., "Interpretation of near-infrared spectroscopy signals: a study with a newly developed perfused rat brain model”, Journal of Applied Physiology, Vol. 90 (2001), pp.1657-1662

(7) Jarque, M., Bera, A.K., Jarque, C.M., Bera, A.K., "A Test for Normality of Observations and Regression Residuals", International Statistical Review, Vol.55, No.2 (1987), pp.163-172.

(8) 開一夫, 松田剛, “インタラクティブゲームにおける脳血流変化”, 株式会社キャラ研スカラシップ研究発表 (2002).

(9) 片寄晴弘, 奥平啓太, 橋田光代, “音楽における没入感に関する検討一技能の拡張と身体性の視点から一音楽と工 ンタテインメント”, 日本バーチャルリアリティ学会誌, Vol.9, No.1 (2004), pp.10-14.

(10) Atkinson, J.L., Anderson, R.E., Sundt, T.M. Jr., “The effect of carbon dioxide on the diameter of brain capillaries", Brain Research, Vol.517 (1990), pp.333-340.

(11) Paulson, O.B., Hasselbalch, S.G., Rostrup, E., Knudsen, G.M., Pelligrino, D., "Cerebral blood flow response to functional activation”, Journal of Cerebral Blood Flow and Metabolism, Vol.30 (2010), pp. 2-14.

(12) 斎藤直, 深見忠典, 柳田裕隆, 高橋龍尚, 新関久一, “近赤外分光法によるへモグロビン濃度測定は血流速度変化 の影響を受けない”, 生体医工学, Vol.49, No.1 (2011), pp.185-190. 